\title{
ADAKAH ITU: VERITAS ET IUSTITIA? ${ }^{1}$
}

\author{
Budiono Kusumohamidjojo \\ email: budikoesoemo@gmail.com
}

\begin{abstract}
The idea of truth has gone through a path of a long history and will still be the subject of a long and complex discourse. It will even remain being the cause of violent conflicts, the more if it deals with the perception of absolute truth. The unfortunate problem befalling mankind is the fact, which is based on different perceptions of truth, let alone "absolute truth", that a lot of people strive to uphold perfect justice as if the world has a place for such an illusion. The history of mankind has reached a stage, whereby we must learn to understand that we have to distance ourselves from thoughts of promoting absolute truth, the more if aspirations toward upholding perfect justice also piggy backs thereon. Or else the world will keep constantly embroiled in senseless conflicts, violence and wars, where people would fight each other for their respective absolute principles, while actually being unaware about its absurd logic. Therefore the newly launched journal Veritas Et Iustitia would have to confront a tremendous challenge because the editors should construct a platform for continuous dialogue leading to constructive efforts towards better understanding about truth which should be increasingly more true and justice which should be increasingly more just to be pursued by mankind.
\end{abstract}

Keywords:

truth, justice, history, absolutism, ideology, paradoxically

\begin{abstract}
Abstrak
Ide kebenaran telah melalui jalur sejarah panjang dan akan masih menjadi subjek wacana yang panjang dan rumit. Bahkan akan tetap menjadi penyebab konflik kekerasan, lebih lagi bila berkaitan dengan persepsi kebenaran mutlak. Kemalangan yang menimpa umat manusia adalah kenyataan banyaknya persepsi berbeda-beda dari kebenaran, apalagi "kebenaran mutlak", dan berdasarkan itu, kemudian orang-orang berupaya menegakkan keadilan sempurna seakan-akan dunia memiliki tempat untuk ilusi tersebut. Sejarah umat manusia telah mencapai tahap, di mana kita harus belajar untuk tidak mempromosikan kebenaran mutlak, terutama bila ikhtiar menegakkan keadilan sempurna turut membonceng gagasan kebenaran mutlak tersebut. Jika hal ini tidak dilakukan umat manusia akan terus terlibat dalam konflik tidak masuk akal, kekerasan dan perang, di mana prinsip-prinsip absolut dipertarungkan satu sama lain. Jurnal yang baru diluncurkan Veritas Et Iustitia harus menghadapi tantangan yang luar biasa. Para editor harus membangun platform untuk dialog terus menerus yang mengarah pada upaya konstruktif menuju pemahaman yang lebih baik tentang kebenaran yang harus semakin benar dan keadilan yang harus semakin adil.
\end{abstract}

Kata kunci:

kebenaran, keadilan, sejarah, absolutisme, ideologi, paradoks

1 Naskah untuk edisi perdana Jurnal "Veritas et Justitia“, Fakultas Hukum UNPAR. 


\section{Idea Kebenaran}

Hatta, tatkala Kaisar Tiberius Julius Caesar (42 SM -37 TM) memerintah di Kekaisaran Romawi (14 TM - 37 TM) menggantikan ayah tirinya Imperator Caesar Divi Filius Augustus (63 SM -14 TM), Pontius Pilatus menjabat sebagai Gubernur provinsi Yudea di Palestina (masa jabatan 26-36 TM). Bertanyalah dia kepada tawanannya Yesus dari Nasareth: “Apakah kebenaran itu?” Lalu menjawablah yang ditanya dengan pernyataan: "Akulah jalan, kebenaran dan kehidupan."2 Yesus dari Nasareth kemudian dihukum mati. Di pulau Jawa 14 abad kemudian dikenal nama Syekh Siti Jenar (lahir 1426 TM-)³ yang tersohor dengan ajarannya Manunggaling Kawula Gusti (dari bahasa Kawi: Bersatunya rakyat dengan Tuhan), dalam mana juga mashur pernyataannya "Ana al-Haq" (dari Arab: Akulah Kebenaran). Syekh Siti Jenar kemudian juga dihukum mati.

Sekarang hampir tidak ada lagi orang yang mengaku dirinya adalah kebenaran, tetapi masih banyak sekali orang yang mengklaim sudah sampai atau memiliki atau telah menguasai kebenaran. Lebih serius lagi adalah, bahwa yang mereka klaim itu adalah "kebenaran mutlak". Padahal kita masih berkewajiban untuk lebih dulu menjelaskan apa sebetulnya kebenaran itu, jika kita hendak membela atau menegakkannya, persis seperti yang ditanyakan oleh Bernard Williams (1929-2003): “What about truth itself?” yang dia jawab sendiri: “... we should resist any demand for a definition of truth, principally because truth belongs to a ramifying set of connected notions, such as meaning, reference, belief, and so on, and we are better employed in exploring the relations between these notions than in trying to treat one or some of them as the basis of the others." Dia juga mengingatkan, bahwa kebenaran itu merupakan konsep yang tak dapat didefinisikan, seperti sudah lebih dulu dikemukakan begitu oleh George E. Moore

2 Injil Yohannes 18:38, dikutip juga oleh Jujun Suriasumantri, Filsafat Ilmu: Sebuah Pengantar Populer (Jakarta, Pustaka Sinar Harapan, 1994), hlm. 36.

3 Biografi Singkat Syekh Siti Jenar, Oleh: Maula Nusantara | Agustus 29, 2011, dalam: https://maulanusantara.wordpress.com/2011/08/29/biografi-singkat-syekh-siti-jenar/ (201502-20). Terdapat berbagai macam versi mengenai cara maupun tahun mangkatnya Syekh Siti Jenar, lihat antara lain: Aji Raksa, 7 Versi Kematian Syekh Siti Jenar, dalam http://ajiraksa.blogspot.com/2012/05/7-versi-kematian-syekh-siti-jenar.html (2015-02-20). 
(1873-1958), Bertrand Russell (1872-1970) dan Gottlob Frege (1848-1925), serta dibuktikan oleh Alfred Tarski (1901-1983). ${ }^{4}$

Sikap Williams itu tidak baru, karena di Tiongkok pernah aktif seorang pemikir yang bernama Mozi dan di Eropa dikenal dengan nama Micius (469-399 SM) serta mendirikan ajaran yang dia namai Mojia (Mohisme). Mozi tidak mempermsalahkan apakah itu yang disebut "pengetahuan" atau "identitas", apalagi "kebenaran" seperti yang begitu dikerubut dalam tradisi filsafat Yunani dan kemudian mewarnai diskursus filsafat Yahudi, Barat maupun Islam, ${ }^{5}$ melainkan lebih berusaha untuk menempatkan pemahaman mengenai suatu konsep dalam hubungan yang relasional. Kunci filsafat Mozi terletak dalam doktrinnya yang membedakan shiyi (yang benar) dari feiyi (yang bukan benar) dan dengan metode begitu juga memisahkan yang berguna (shiyong de) dari yang tidak berguna (feiyong de). ${ }^{6}$ Mohisme memang boleh dipandang sebagai pendahulu dari Utilitarianisme yang kemudian akan dirintis oleh Jeremy Bentham (1748-1832) dan dikembangkan oleh John Stuart Mill (1806-1873). Metode Mozi itu analog dengan doktrin kaum Mingjia yang lebih tua lagi (Aliran Dialektik, abad 6-3 SM) yang pragmatis dalam menyatakan objek adalah (shi) "kuda" dan bukanlah (fei) "sapi”, karena "kuda” tidaklah mungkin adalah sekaligus "sapi”. Kita tahu, bahwa Aristoteles (384-322 SM) kemudian memaklumkan pemahaman ini sebagai "doktrin identitas". Orang-orang Mojia dan Mingjia dengan begitu tidak tenggelam dalam kisaran ruang pikir Platon (428/427 atau 424/423 - 348/347 SM) yang memasalahkan apa itu "kuda" dan "kekudaan" (atau pada tataran ontologi: "benar" dan "kebenaran").

Meskipun demikian, ajaran para pemikir Mojia dan Mingjia belum menjelaskan pertanyaan, dari mana konsep mengenai "kebenaran" itu hinggap pada akal manusia? Jika menyusuri pikiran Immanuel Kant (1720-1804), konsep

\footnotetext{
${ }^{4}$ Bernard Williams, Truth and Truthfulness (Princeton and Oxford, Princeton UP, 2002), hlm. 63.

${ }^{5}$ Karen Armstrong, A History of God (London, Mandarin, 1995).

${ }^{6}$ Chris Fraser, Mohism, http://plato.stanford.edu/entries/mohism/ (2015-03-30); Liu JeeLoo, An Introduction To Chinese Philosophy: from Ancient Philosophy to Chinese Buddhism (Malden MA, Blackwell, [2006] 2008), hlm. 125, mengutip naskah Mòzĭ, part I, ch. 35.
} 
itu datang dari kemampuan akal murni yang merupakan kodrat manusia dan mampu menjelajah alam transendental, yaitu alam yang mengatasi dirinya dalam cakupan ruang dan waktu: "Sekarang kita tidak hanya telah menjelajahi negeri akal murni dan memperhatikan secara seksama setiap bagian daripadanya, melainkan juga telah mengukurnya dan memastikan setiap hal pada tempatnya sendiri-sendiri. Namun demikian negeri itu adalah suatu pulau yang dikurung oleh alam dalam batas-batas yang tidak berubah-ubah. Negeri itu adalah negeri kebenaran (suatu nama yang merangsang), dikelilingi oleh lautan yang luas dan ganas, tempat yang sesungguhnya bagi berbagai penampakan, di mana sabuk kabut dan gunung es yang cepat mencair seolah menampakkan negeri-negeri baru, yang tidak henti-hentinya mengelabui pelaut-pelaut yang mengitarinya dengan harapan-harapan hampa, menceburkan mereka ke dalam petualangan yang tidak pernah dapat mereka tinggalkan dan juga tidak pernah dapat mereka akhiri".7

Dalam kontruksi Kant, "negeri akal murni" itu bersemayam dalam "pemahaman kognitif pra-pengalaman" sebagaimana ditawarkan oleh berbagai ilmu, tetapi terutama oleh matematika. ${ }^{8}$ Konstatasi Kant ini sebetulnya juga bukan cerita baru, karena sebelumnya Aristoteles di samping memaklumkan hakikat manusia sebagai anthropos physei politikon zoon (dari alamnya manusia itu adalah makhluk politik), dia juga menyatakan manusia sebagai zoon logon echon (makhluk yang bernalar) yang secara hakiki membedakannya dari makhluk subhuman. Masih dalam kerangka Aristoteles, kemampuan menalar itulah yang membuat manusia bertanya, dan seharusnya tidak berhenti bertanya, termasuk bertanya mengenai hal-hal tidak jelas yang kerap diperlakukan sebagai kebenaran.

\footnotetext{
7 Immanuel Kant, Kritik der reinen Vernunft (Königsberg, 1787, edisi Stuttgart, Philipp Reclam Jun., 1975), hlm. 322.

8 Theodor Valentiner, Kant und seine Lehre, eine Einfuhrung in die kritische Philosophie (Stuttgart, Philipp Reclam Jun., [1960] 1976).
} 


\section{Kebenaran dan Absolutisme}

Kurang lebih lima setengah abad setelah peristiwa Syekh Siti Jenar, ketika untuk pertama kalinya saya harus ke kampus utama Julius-MaximiliansUniversität Würzburg di Jerman dalam musim semi tahun 1977, saya membaca perkataan "Veritas" (dari Latin: kebenaran) ditulis besar-besar di atas gerbang masuknya, seperti cocok benar dengan kemegahan arsitektur Barock bangunan itu. Ketika itu saya berkata lugu dalam hati: "Hebat". Saya lugu karena belum menyadari dampak paradoksal dari "veritas.” Ketika itu saya termasuk yang masih larut dalam ujar-ujar latah yang percaya bahwa "kebenaran pasti menang." Universitas itu didirikan pada tahun 1582, kurang lebih tiga dasa-warsa sebelum Perang Tiga Puluh tahun di Eropa yang pecah atas nama "veritas" juga. Dalam Perang itu orang saling bunuh karena masing-masing mengklaim kebenaran dan meminta korban antara tiga sampai tujuh juta orang sebelum diakhiri oleh Perjanjian Westphalia di Münster dan Osnabrück. ${ }^{9}$ Selama kurang lebih satu setengah abad, Perjanjian Westphalia menjamin perdamaian di Eropa sampai datangnya Napoleon Bonaparte (1769-1821). Sang Penakluk Eropa itu tidak menyoal "kebenaran" melainkan mengibarkan panji Revolusi Prancis tahun 1789: Liberté, Egalité et Fraternité (kemerdekaan, persamaan dan persaudaraan) untuk menggempur tembok absolutisme Eropa yang mengklaim kebenaran demi kenikmatan para penguasa feodal. Napoleon memang merubah stelsel sosialpolitik internasional, terutama Eropa, tetapi dia tidak merubah stelsel berpikir manusia yang absurd mengenai kebenaran, apalagi kebenaran mutlak.

Sekira 30 tahun kemudian setelah menampak "Veritas" saya akan sering ke kompleks Lemhannas, yang di dalam Gedung Asthra Gatra dapat kita baca seloka "TANHANA DHARMMAMANGRVA" (dari Sanskerta: "Tiada Kebenaran yang Mendua"), dan saya mengatakan kepada diri sendiri, masih dengan lugu juga: "seharusnya begitu."

\footnotetext{
${ }^{9}$ Dreißigjähriger Krieg, dalam Wikipedia, http://de.wikipedia.org/wiki/Drei\%C3\%9Figj\%C3\%A4hriger Krieg (2015-02-20).
} 
Tetapi sekitar sepuluh tahun kemudian, jika saya mendengar atau membaca ungkapan yang kurang lebih berbunyi "kebenaran pasti menang”, "demi kebenaran dan keadilan", atau "menegakkan kebenaran dan keadilan", saya terusik dalam hati untuk bertanya "Ah, masa'?" atau "Kata siapa?" atau "Kebenaran dan keadilan yang mana?" dan kemudian malahan mempertanyakan “Apakah memang ada kebenaran dan keadilan itu?" “Apakah bukannya adalah lebih benar bahwa banyak sekali orang sok tahu apa itu kebenaran dan lebih keblinger lagi mengaku telah memiliki kebenaran?" Karena memang begitulah pertanyaan yang saya dapatkan sebagai jawaban dalam penjelajahan naluri tanyajawab nalari yang tidak dapat saya hindari selama itu dalam berhadapan dengan realitas. Dan sebetulnya pertanyaan itu juga bukan dongeng baru, sebagaimana banyak contohnya dalam sejarah. Sejarah dunia maupun sejarah Indonesia kaya dengan kisah tragis mengenai klaim maupun perebutan "kebenaran." Lebih absurd lagi: semakin absolut klaim kebenaran yang diperjuangkan, semakin berdarah-darah juga tragedi yang dihasilkannya. Tetapi nampaknya manusia tidak atau belum belajar banyak sejak awal sejarahnya sendiri, karena sangat kentara bahwa kebodohan mengenai kebenaran, apalagi yang absolut, bertahan sematamata karena kemalasan menalar yang menghasilkan mentalitas "dari dulu sudah begitu". Itu adalah kebiasaan berpikir yang tidak hanya umum di antara para birokrat yang suka berpuas diri, tetapi celakanya juga di kalangan sementara politisi nasional dan bahkan tokoh-tokoh internasional. Di antara sedikit kekecualian orang yang masih mencoba membuka cakrawala baru dalam abad ke20 adalah John Winston Lennon (1940-1980) lewat karyanya Imagine.

Jadilah kelanjutan bahwa ada lebih banyak orang yang terus bertengkar dan bahkan saling menghabisi gara-gara "kebenaran", tetapi dalam pola yang mirip dengan polisi yang menangkap pencuri dan menuduh si pencuri telah mencuri barang yang belum tentu ada, selagi si pencuri membantahnya dengan mengatakan bahwa dia belum pernah melihat barang yang belum tentu ada itu. 
Xenophanes (570-ca. 480 SM) ${ }^{10}$ dan Parmenides (ca. 515-ca. 450 SM) dari Yunani yang kemudian juga akan banyak mengilhami pikiran Barat sudah menyadari teka-teki itu sembari mengingatkan, bahwa karena keterbatasannya manusia tidak mungkin menggapai kebenaran yang sebenar-benarnya. Sedangkan Konfusius (551-479 SM) dari Timur yang hidup dalam kurun waktu yang sejajar menyatakan bahwa "pencarian kebenaran" itu malahan "bukan urusan manusia", yang bahkan tentang hidup keseharian ini saja sering kali tidak memiliki kejelasan. ${ }^{11}$

Karena orang sebetulnya tidak tahu persis apa kebenaran itu, saya menengarai bahwa perebutan atau perjuangan demi suatu kebenaran (tertentu) yang kerap kali menjadi persoalan hidup atau mati dari banyak orang yang berdosa maupun tidak berdosa itu dimotivasi oleh sesuatu kapasitas manusia yang lain selain dari kompleks penalaran yang telah menghasilkan pengetahuan. Kapasitas yang selain menalar itu juga mencakup intuisi, persepsi dan bahkan juga mythos, ${ }^{12}$ yang sebaiknya kita teliti ulang atau bongkar lebih jauh untuk mengakhiri serta mencegah penderitaan banyak orang yang sebetulnya tidak terlalu memusingkan apa itu kebenaran, untuk selanjutnya menghindari tersandungnya manusia pada batu prahara yang sama untuk kesekian kalinya dalam sejarah. Jadi dalam upaya untuk memahami "kebenaran", kebanyakan orang sebetulnya tidaklah lebih cerdas dari keledai. Untuk kebanyakan orang, tanpa mereka pernah menyatakannya: menyoal kebenaran adalah urusan dari para pemikir yang berbudi luhur, rajin dan cerdas, yang hidup dan bekerja di puncak menara gading yang tak pernah didirikan. Persepsi itu sebetulnya lantas berbagi satu platform dengan aspirasi, bahwa tidak penting apakah negara itu diperintah oleh kaum kapitalis, komunis atau bahkan anarkis, atau apakah dikuasai oleh penguasa yang demokratis, diktator atau despot, karena yang

\footnotetext{
10 Xenophanes pernah menyatakan, kurang lebih begini: “... andaikata sapi dan kuda bisa berimajinasi, maka sapi dan kuda akan membayangkan Tuhan itu sebagai berwujud sapi atau kuda juga," http://en.wikipedia.org/wiki/Xenophanes (2015-03-31).

11 Konfusius dalam Lùn-yŭ: XI.11. (Lùn-yü: dialog), dari: Konfuzius, Gespräche. Lun Yü, terjemahan Richard Wilhelm (München, dtv CH Beck, [2005] 2007).

12 Franz Martin Wimmer, Interkulturelle Philosophie (Wien, WUV Facultas, 2004).
} 
penting adalah bahwa rakyat hidup aman dan makmur dan pada umumnya menikmati keadilan yang paling sedikit adalah keadilan yang suam-suam kuku. Padahal, bukankah sistem, sistem apapun itu, selalu hanya merupakan metode untuk mencapai suatu tujuan tertentu? Bukankan sistem atau doktrin atau teori atau kebenaran apapun selalu butuh (subject to) verifikasi yang terus menerus? ${ }^{13}$

\section{Keadilan berdasarkan Kebenaran}

Lebih celaka lagi, atas dasar kebenaran yang sebetulnya belum pernah sempat mangkal di manapun dalam perjalanan sejarah tetapi masih terus diklaim dan diperebutkan itu konon katanya harus ditegakkan "iustitia" (dari Latin: keadilan). Jadi selagi orang masih terus berselisih mengenai kebenaran, atas dasar premis yang tidak kunjung definitif itu orang sudah hendak menegakkan keadilan, yang nota bene juga merupakan konsep yang karenanya juga tidak mungkin bebas dari polemik. Itu mirip dengan orang yang bertekad menjadi juara sprint, sambil dia sebetulnya baru menduga-duga belaka, bahwa dia memang mempunyai kaki. Atau, jika boleh meminjam gaya René Descartes (1596-1650): orang yang jumawa hendak berpikir, tetapi sebetulnya belum tahu apakah dia mempunyai kepala. Kekeliruan cara berpikir serupa itu dalam logika disebut argument non sequitur: menarik kesimpulan dari alasan-alasan yang tidak jelas, atau lebih gila lagi: tidak ada, sehingga menghasilkan kesimpulan yang tidak "nyambung" dengan alasan apapun. Dengan begitu orang melanjutkan perjalanan sejarah dengan pindah dari ruang gelap ilusi yang satu untuk mencari kucing hitam ideologis yang orang belum pernah melihatnya, ke ruang gelap ilusi yang lain untuk menangkap kucing hitam ideologis yang belum tentu pernah dirumuskan. Dalam ruang ketidakjelasan itu di Indonesia orang malahan dengan serius mengangkat adagium dari negarawan Romawi, Lucius Calpurnius Piso Caesoninus (ca. 100-43 SM), dan menjadikannya motto organisasi pencari keadilan pula: "Fiat justitia ruat caelum"

\footnotetext{
13 Sir Karl Raimund Popper (1902-1994): Conjectures and Refutations: The Growth of Scientific Knowledge (London, Routledge, 1963); Thomas Kuhn (1922-1996): The Structure of Scientific Revolutions (Chicago, University of Chicago Press, 1962).
} 
(mari tegakkan keadilan, sekalipun langit runtuh). Padahal, seperti sindir Amartya Sen: apa gunanya keadilan jika langit sudah runtuh? ${ }^{14}$ Untungnya langit tak kunjung runtuh, sehingga "penegakan keadilan" masih bisa terus dilanjutkan melalui aneka debat kusir dengan justifikasi yang dicari dan dibuat di pengadilan, di kantor polisi dan tak urung juga di parlemen yang tidak jarang memang seperti taman kanak-kanak, tidak hanya di Indonesia, tetapi juga di banyak negara lain. "Rasa keadilan" yang serupa itulah yang mengakibatkan seorang nenek yang "mencuri" tiga buah coklat atau nenek yang "mencuri” beberapa batang kayu jati di tanahnya sendiri dihukum penjara, selagi para pejabat tinggi berdebat tanpa hati nurani mengenai rumus untuk menetapkan remisi bagi para koruptor besar yang membuat berjuta orang menganggur, berjuta ibu menderita dan berjuta anak tidak mempunyai masa depan yang pantas mereka jelang.

Domitius Ulpianus yang ahli hukum Romawi (170-223) memang pernah (berusaha) merumuskan apa itu keadilan dalam karyanya Digest iustiniani sebagai "suum quique tribuere" (dari Latin: memberikan kepada siapapun apa yang menjadi haknya). ${ }^{15}$ Tetapi rumusan ini pun kemudian tidak luput dari kritik tajam, antara lain dari Hans Kelsen (1881-1973) dan Bernd Rüthers (1930-). Menurut mereka rumus "memberikan kepada siapapun apa yang menjadi haknya" itu merupakan rumus yang hampa justru karena tidak pernah jelas apa yang menjadi "hak" itu dan apa isinya,16 karena setiap individu akan merumuskan haknya menurut persepsi dan interesenya sendiri-sendiri. John Rawls (1921-2002) serta Michael Sandel (1953-) kemudian malahan akan memperkuat argumen ini dengan mengindikasikan, bahwa persepsi mengenai keadilan itu berbeda dari orang ke orang dan dari konstelasi ke konstelasi situasional yang berbeda pula. ${ }^{17}$

\footnotetext{
${ }^{14}$ Amartya Sen, The Idea of Justice (London, Penguin Group, 2010), hlm. xv, 20-21, etc.

15 Lengkapnya dikutip oleh Heinrich Honsell: "Iustitia est constans et perpetua voluntas ius suum quique tribuendi. Ius praecepta sunt haec: honeste vivere, alterum non laedere, suum quique tribuere" dalam Römisches Recht (Berlin/Heidelberg/New York, Springer, 2002), hlm. 19.

16 Hans Kelsen, Was ist Gerechtigkeit? (Stuttgart, Philip Reclam, (1953) 2010), hlm. 32; Bernd Rüthers, Das Ungerechte an der Gerechtigkeit (Tübingen, Mohr Siebeck, 2009), hlm. 160 dst.

17 John Borden (Bordley) Rawls, A Theory of Justice (Harvard UP, (1971) 1991); Sandel, Michael, Justice: What's the Right Thing to do? (New York, Farrar, Straus \& Giroux, 2009).
} 
Karena itu orang lantas perlu kembali kepada keseharian Lebenswelt (Edmund Husserl, 1859-1338) di mana orang merealisasikan diri dan merumuskan jati dirinya sendiri. Di situ juga jika mau, orang bisa memulai itikad baik untuk dengan tulus menjelajahi medan pencarian keadilan yang membonceng pada kebenaran yang jangan sekali-kali diabsolutkan, terutama karena manusia sendiri tidak absolut. Refleksi itu saya jumpai dalam penjelasan yang dikemukakan oleh Satjipto Rahardjo (1930-2010) dengan meminjam Serat Sasangka Jati: “... adil adalah tegak, tidak berat sebelah, oleh karena itu juga bisa diberi arti lurus atau benar, sedang benar itu juga berarti nyata, dan nyata itu adalah jujur..."18 Teranglah bahwa rumusan ini lebih kompleks dari apa yang saya sebut "keadilan" itu sebagai proses give and take yang timbal-balik dan seimbang dalam kebersamaan hidup yang multi kompleks dan paradoksal, terutama karena dia harus bertolak dari kejujuran. Padahal kejujuran itu tidak pernah merupakan milik dari massa kolektif yang tak berwajah, melainkan bersemayam dalam individu yang mandiri sehingga mampu dan berpeluang untuk menorehkan jiwa yang manusiawi kepada kolektif. Dalam konteks Serat Sasangka Jati bukan hanya soal ukur-mengukur berat sebelah atau tidak berat sebelah yang menghasilkan keadilan, melainkan pada akhirnya adalah sikap jujur yang nota bene menyentuh dimensi hati nurani individu masing-masing. Untuk setiap individu berlaku: "hanya saya saja yang tahu, apakah saya sungguh jujur dalam hal tertentu atau dalam semua hal yang saya hadapi dalam hidup." Jika kemudian dipancarkan pada tataran kehidupan bersama, umat manusia memang tidak bisa tegak dengan mengandalkan kebohongan untuk kemudian mengabdi kepada absolutisme.

\section{Misi Perenial para Cendekia}

Klaim yang marak seolah-olah subjek telah memiliki kebenaran harus digeser menjadi usaha yang tekun dan konsisten untuk terus menerus memperbaiki rumusan mengenai kebenaran menjadi rumusan yang dari waktu ke

\footnotetext{
18 Satjipto Rahardjo, Ilmu Hukum (Bandung, PT Citra Aditya Bhakti, 2000), hlm. 166.
} 
waktu menjadi pemahaman mengenai kebenaran yang juga terus menerus menjadi lebih benar. Sebetulnya individu berkewajiban untuk menorehkan jiwa yang manusiawi ke dalam kolektif, atau kolektif itu akan memperoleh sifat hakiki tidak berbeda dari sekawanan lebah sehingga menjadi tidak relevan dalam sejarah. Karena itu individu juga terikat pada keniscayaan untuk menjalankan dialog, persis seperti yang difahami oleh Jürgen Habermas (1929-). Dalam kerangka pikir Habermas pertengkaran-pertengkaran yang berangkat dari argumen-argumen a priori (seperti yang terutama berkenaan dengan thema kebenaran) harus ditransformasi ke dalam rangkaian tindakan komunikatif (Jerman: kommunikatives Handeln) yang terus-menerus. Sejarah memang merupakan proses terus menerus yang infinit, yang memang tidak bisa lain, dalam mana dialog bisa atau bisa tidak berujung dalam tindakan komunikatif. Jangan anggap enteng: berkomunikasi tidak layak dipandang gampang, dan dialog adalah lebih tidak gampang lagi. Produk dari dialog yang tidak berujung dalam tindakan komunikatif adalah konflik, kekerasan, perang. Proses tindakan komunikatif untuk meniti kelangsungan sejarah itu dalam praksisnya bertumpu pada penyelenggaraan argumentasi. Dalam kerangka itulah argumentasi mendapatkan peranan dalam membuat setiap subjek tetap bisa hadir dalam hubungan sosial. Habermas tidak memahami argumentasi sebagai institusi yang baku, melainkan lebih sebagai proses pertukaran serta penilaian informasi, prinsip-prinsip serta terminologi, karena semua itu pada akhirnya akan diungkapkan dalam kata-kata baru yang memungkinkan diungkapkannya penguraian-penguraian makna yang mengalami revisi akibat dinamik dari Lebenswelt masyarakat. Tindakan komunikatif memang lebih mengandalkan diri pada interpretasi dan interese timbal-balik (yang dinamis), ketimbang kepada logika (yang baku), yang memang bukan segala-galanya bagi Habermas. Mengikuti Jacques Derrida (1930-2004), dia menulis: "Logika itu mendahului gramatik, dan fungsi mengetahui mendahului 
fungsi memahami."19 Jadi logika itu baru bagian permulaan dalam suatu rangkaian tindakan komunikatif.

Masih mengikuti Aristoteles yang memaklumkan logika sebagai Organon semata, juga Habermas memandang logika sebagai instrumen tetapi bukan hasil akhir dari argumentasi. Sepakat dengan Charles Sanders Peirce (1839-1891) dia juga menyatakan argumentasi sebagai bagian terpenting dari proses belajar yang refleksif bagi subjek. ${ }^{20}$ Kendati begitu proses argumentasi itu harus secara pragmatis memprasyaratkan para subjek peserta argumentasi, bahwa pada prinsipnya semua subjek peserta terlibat secara bebas dan setara dalam proses kerjasama pencarian kebenaran, dalam proses mana hanya argumen yang lebih baik yang boleh dipaksakan. ${ }^{21}$ Terang bahwa argumentasi model Habermas mensyaratkan suatu situasi ideal yang masih jauh panggang dari api di banyak bagian muka bumi ini, terutama di negara-negara tertinggal dalam modernitas atau masyarakat-masyarakat yang berkebudayaan tertutup. Karena itu kebebasan dan kesetaraan dalam kerjasama pencarian kebenaran itu lebih gampang dibilang ketimbang dijalankan. Belum lagi kalau kita bicara tentang "argumen yang lebih baik" yang belum apa-apa pastilah sudah akan menjadi perkara sendiri dalam suatu dialog yang ideal sekalipun. Jangan lupa, bahwa adalah "argumen yang lebih baik“ yang justru selalu dijadikan ujung tombak dalam perjuangan ideologi. ${ }^{22}$

Argumen yang menjadi tumpuan tesis Habermas itu bersemayam dalam bahasa, yang dalam kerangka pikir Mojia seperti yang sudah disinggung di atas harus dipandang selalu sebagai bersifat relasional. Karena itu "bahasa" yang dalam filsafat konvensional kita dewasa ini merupakan piranti utama dalam diskursus untuk menemukan "kebenaran" seperti difahami dalam filsafat Barat,

19 Jürgen Habermas, Der philosophische Diskurs der Moderne (Frankfurt/Main, Suhrkamp, [1985] 1998), hlm. 204.

${ }^{20}$ Habermas, Erläuterungen zur Diskursethik (Frankfurt/Main, Suhrkamp, [1991] 1992), hlm. 164165.

${ }^{21}$ Habermas, Erläuterungen zur Diskursethik, hlm. 61.

22 Argumen Habermas ini sudah lebih dulu saya kemukakan dalam risalah saya: "Kebudayaan Dalam Stelsel Habermas", dalam MELINTAS, Jurnal Filsafat dan Teologi, Agustus-November 2004, dan dalam buku saya Filsafat Kebudayaan: Proses Realisasi Manusia (Yogyakarta, Jalasutra, 2009), hlm. 114-115. 
harus lebih didaya-gunakan untuk melaksanakan Dao, yaitu jalan yang benar (ketimbang jalan yang tidak benar) dalam kehidupan subjek dan untuk diterapkan selanjutnya dalam kehidupan sosial yang selalu relasional. ${ }^{23}$ Perintah Dao itu sederhana saja, dan mirip dengan kategori imperatif dari Kant ${ }^{24}$ di kemudian harinya: jika berkata jujur itu benar (shiyi) sedangkan berkata tidak jujur itu tidak benar (feiyi), maka jalankanlah yang shiyi. Dan tidak perlu kita mempertengkarkan apa yang mutlak benar di antara keduanya. Fritjof Capra menulis buku yang sangat berharga untuk menjelaskan relasi ini. ${ }^{25}$

Mirip dengan pikiran kaum Utilitarian Inggris dua milenia kemudian, Mozi berargumen, bahwa tindakan itu harus diukur menurut patokan, bagaimana tindakan itu dapat menyumbang bagi "manfaat terbesar untuk rakyat terbanyak" (aslinya dalam bahasa kaum Utilitarian Inggris: "the greatest good of the greatest number'). Pandangan ini mengingatkan kita pada dua filosof Inggris, Jeremy Bentham dan John Stuart Mill yang umumnya dipandang sebagai pelopor kaum Utilitarian. ${ }^{26}$ Kendati demikian dalam kenyataan, "manfaat terbesar untuk rakyat terbanyak" adalah doktrin yang masih jauh dari domain penjelasan bagi idea mengenai kebenaran. Konsep "manfaat" adalah jauh dari memadai untuk mengatasi jurang antara keterbatasan eksistensial manusia dan ketidakterbatasan hasrat serta ambisi-ambisinya.

Ketidak-terbatasan hasrat serta ambisi-ambisinya yang mengakibatkan bahwa manusia itu bukanlah makhluk yang sekadar hidup untuk besok, dan dia juga tidak sekadar memburu masa depan yang lebih baik, tetapi dia merupakan suatu jenis makhluk yang bisa melintasi berbagai batas aneka dimensi realitas, seperti kata Wolfgang Wickler (1931-), seorang ahli biologi: manusia itu adalah makhluk yang selalu menghendaki lebih ketimbang yang dia bisa, dan selalu bisa

\footnotetext{
${ }^{23}$ Fraser, Mohism, hlm. 18.

${ }^{24}$ Immanuel Kant, Grundlegung zur Metaphysik der Sitten (Riga, Johann Friedrich Hartknoch, 1786; edisi Suttgart, Philipp Reclam Jun., 1976), terutama hlm. 68.

25 Capra, Fritjof, The Tao of Physics: An Exploration of the Parallels Between Modern Physics and Eastern Mysticism (Toronto/New York/London, Bantam, [1975] 1980).

26 Budiono Kusumohamidjojo, Filsafat Tiongkok: Sebuah Pengantar Komprehensif (Yogyakarta, Jalasutra, 2010), hlm. 126.
} 
lebih, ketimbang yang dia dibolehkan, ${ }^{27}$ sambil manusia sering lupa atau lebih parah lagi: manusia bisa tidak mau tahu, bahwa dia dibelenggu oleh keterbatasan eksistensial. Singkat kata, manusia itu akan selalu berjuang untuk mencapai lebih, sebetulnya sambil terus-menerus berhasrat untuk memperbarui rumusannya sendiri tentang apa yang boleh dan apa yang tidak boleh baginya. Manusia akan terus berusaha melintasi batas-batas dirinya sendiri, persis seperti Karl Jaspers (1883-1969) pernah menyatakannya: "Manusia adalah selalu lebih dari apa yang dia bisa mengerti tentang dirinya sendiri."28 Akibatnya, manusia itu akan selalu terjerumus dalam balapan kura-kura Zenon (ca. 490-ca. 430 SM) ${ }^{29}$ yang tidak akan pernah mencapai garis finish pemahaman dirinya. Logika sederhananya adalah: jika manusia tidak akan pernah bisa menyelesaikan infinitas hasratnya, seharusnya manusia juga "tahu diri" dan tidak mengajukan, memperjuangkan dan apalagi mempertahankan sesuatu yang absolut yang sebetulnya dia tidak tahu benar atau malahan sebetulnya potensial tidak tahu sama sekali, in casu: kebenaran mutlak.

Apalagi jika kita tidak bisa menghindari tendens bahwa konsep kebenaran itu merupakan kulminasi dari pemahaman moral manusia mengenai yang benar atau tidak benar yang nota bene pada akhirnya harus diakui sebagai "karangannya" sendiri juga. Fenomen ini dijelaskan oleh Friedrich Nietzsche (1844-1900) dalam bukunya Jenseits von Gut und Böse (Di Seberang Baik dan Jahat). ${ }^{30}$ Apa yang dijelaskan oleh Nietzsche sebetulnya logis belaka, tetapi nyatanya sampai hari ini di seluruh dunia orang masih mengklaim memiliki atau "sok" paling tahu mengenai apa itu kebenaran sambil menggelantung pada suatu

27 Dalam Peter Kunzmann, Franz-Peter Burkard, dtv-Atlas Philosophie (München, Deutscher Taschenbuch Verlag, [1991] 2005), hlm. 11: "Der Mensch ist das Wesen, das stets mehr will, als es kann, und mehr kann, als es soll."

${ }^{28}$ Karl Jaspers, Der philosophische Glaube (München, Piper \& Co, 1948), hlm. 49.

${ }^{29}$ John Palmer, Parmenides, http://plato.stanford.edu/entries/parmenides/, <jpalmer@phil.ufl.edu>, Copyright (C) 2008 (2015-03-30), hlm. 13; juga: John Palmer, Zeno of Elea, http://plato.stanford.edu/entries/zeno-elea/, <jpalmer@phil.ufl.edu> Copyright @ 2012 (2015-03-30), hlm. 5.

30 Friedrich Nietzsche, Jenseits von Gut und Böse: Vorspiel einer Philosophie der Zukunft (München, Goldmann Verlag, (1886) 1996), Bab V, khususnya hlm. 90-91; Bab IX, khususnya hlm. 153-156. 
otoritas ekstra nalar yang dia percaya, terlepas dari soal apakah dia mengerti atau tidak mengerti, sehingga tidak perlu dijelaskan karena memang tidak niscaya dijelaskan juga, seperti ujar Sigmund Freud (1856-1939): "sebagaimana orang tidak dapat dipaksa untuk percaya, begitu juga orang juga tidak dapat dipaksa untuk tidak percaya."31 Doktrin Freud itu sekaligus menjelaskan akar dari kekerasan yang berdarah-darah di Timur Tengah, Afrika atau Ukraina pada tataran internasional, dan tidak kurang berbagai kekerasan horisontal kambuhan di Indonesia, karena manusia ternyata kelewat sering saling memaksa.

Peradaban manusia perlu belajar dari kebodohan yang "besar pasak dari tiang" dalam mengejar dan memperjuangkan kebenaran mutlak itu. Nampaknya wacana dunia kita dewasa ini perlu menapak pendekatan yang lebih realistik itu dan membebaskan diri dari jebakan identifikasi Platonis yang ideologis untuk bisa menyongsong dan mencerdasi spiral kompleks masalah yang semakin membelenggu umat manusia yang proses realisasinya juga semakin paradoksal. Para pemikir yang menginspirasi para politisi sebaiknya menjauhkan diri dari perjuangan untuk memastikan identifikasi kebenaran terakhir dan keadilan terakhir yang Platonis serta menggeser orientasi kerja keras mereka menuju upaya-upaya untuk membangun pemahaman yang lebih komprehensif menuju kebenaran yang terus menerus lebih benar serta keadilan yang terus menerus lebih adil. Karena, seperti kata Bernd Rüthers dengan nada yang sarkastik: "Barang siapa bersikeras menghendaki keadilan yang sempurna, dia harus mencarinya di alam yang lain." 32 Saran itu berangkat dari plausibilitas yang sederhana belaka: jika orang-orang mengejar keadilan yang sempurna (dalam persepsinya masing-masing) dalam kehidupan bersama yang tidak hanya semakin pluralistik tetapi juga semakin paradoksal, selagi masing-masing memiliki persepsi yang berbeda-beda mengenai keadilan serta bersikukuh

\footnotetext{
31 Sigmund Freud, Massenpsychologie Und Ich-Analyse: Die Zukunft Einer Illusion (Frankfurt/Main, Fischer Taschenbuch Verlag, [1921] 2007), hlm. 135: "So wie niemand zum Glauben gezwungen werden kann, so auch niemand zum Unglauben."

32 Bernd Rüthers, Rechtstheorie (München, CH Beck, 2005), hlm. 2-3.
} 
memaksakannya kepada orang lain, tidaklah mengherankan bahwa modernitas juga akan tidak bebas dari konflik, kekerasan dan perang.

\section{Agenda Realis untuk Veritas Et Iustitia}

Jadi dari namanya Jurnal ini menyimpan dua kemungkinan: dia bisa absurd sama sekali, atau dia berjanji untuk secara tiada henti hendak menggapai kehebatan daya nalar manusia yang nirbatas dan melampaui keterbatasan eksistensialnya sendiri, seperti yang diindikasikan oleh Wickler. Kecil kemungkinan bahwa pendiri jurnal ini hendak mencapai suatu cita-cita yang absurd, sehingga lebih plausible jika yang hendak dicapai adalah tujuan yang kedua. Untuk itu para editor Veritas Et Iustitia akan harus berjuang untuk menempuh perjalanan yang teramat panjang dalam proses regenerasi yang terus menerus untuk mencerahkan nalar manusia guna memahami, bahwa kebenaran dan keadilan itu bukanlah perkara baku, melainkan lebih merupakan idea yang pemahaman terhadapnya serta realisasi daripadanya merupakan kerja yang tidak akan kunjung selesai, tetapi harus dilakukan untuk semakin memanusiakan proses realisasi manusia. Ironi itu mungkin mirip dengan orang yang melihat bayangannya ketika berjalan di bawah sinar bulan dan terus mengikuti langkahnya. Ketika dia berhenti, bayangan proses pemanusiaan itu juga berhenti, padahal sejarah adalah mirip dengan orang yang tidak pernah menghentikan langkahnya, dan karena itu seharusnya diarahkan menuju tujuan yang semakin lama semakin benar dan semakin adil belaka. Jika langkah itu dihentikan, akan jatuhlah dia di pelataran kehampaan pemahaman akan kemanusiaannya sendiri, lumayan mirip dengan orang yang berhenti mengayuh sepedanya, padahal dia belum lagi mencapai tujuannya. ${ }^{33}$

Sekiranya saya telah memaparkan nalar saya di atas dengan jelas dan dapat diterima dengan baik untuk diejawantahkan ke dalam praksis dialog

\footnotetext{
${ }^{33}$ Budiono Kusumohamidjojo, "The terrain of the future: Life will be like bicycle riding", dalam The Jakarta Post, 16 September 2011.
} 
kecendekiaan, redaksi Veritas Et Iustitia akan harus melakukan seleksi terhadap naskah-naskah yang ditawarkan kepada mereka untuk diterbitkan, atau sebaiknya menetapkan kriteria tertentu tatkala redaksi meminta seorang pemikir untuk menulis naskah yang hendak diterbitkan. Nama Jurnal ini meletakkan kewajiban di atas pundak para editornya untuk menghidupkan dan menggalakkan cara berpikir, bahwa tidak ada kebenaran atau keadilan yang absolut, karena yang harus dilakukan manusia adalah terus menerus menorehkan rumusan yang cekak zaman mengenai kebenaran yang lebih benar dan atas dasar itu menegakkan keadilan yang terus menerus semakin adil. Jangan lagi ikut menyuarakan bahwa "kebenaran pasti menang" dan kalau bisa malahan memberi nasehat, agar kita semua bukannya sekadar mau menang (apalagi menang sendiri), melainkan terus berikhtiar dalam kerangka dialog yang komunikatif untuk menegakkan keadilan yang senantiasa lebih adil, supaya langit tidak runtuh!

\section{Daftar Pustaka}

Karen Armstrong, A History of God, London, Mandarin, 1995.

Capra, Fritjof, The Tao of Physics: An Exploration of the Parallels Between Modern Physics and Eastern Mysticism, Toronto/New York/London, Bantam, [1975] 1980.

Fraser, Chris, Mohism, http://plato.stanford.edu/entries/mohism/, 2015-03-30. Freud, Sigmund, Freud, Massenpsychologie Und Ich-Analyse: Die Zukunft Einer Illusion, Frankfurt/Main, Fischer Taschenbuch Verlag, [1921] 2007.

Habermas, Jürgen, On the Logic of the Social Sciences, Cambridge/Mass, The MIT Press, [1967] 1996.

Habermas, Jürgen, Erkenntnis und Interesse, Frankfurt/Main, Suhrkamp, [1968, 1971] 2003.

Habermas, Jürgen, The Theory of Communicative Action - Vol I, Boston/Mass., Beacon Press, [1981] 1984.

Habermas, Jürgen, Der philosophische Diskurs der Moderne, Frankfurt/Main, Suhrkamp, [1985] 1998.

Habermas, Jürgen, Erläuterungen zur Diskursethik (Frankfurt/Main, Suhrkamp, [1991] 1992).

Habermas, Jürgen, Die postnationale Konstellation: Politische Essays (Frankfurt/Main, Suhrkamp, 1998).

Honsell, Heinrich, Römisches Recht (Berlin/Heidelberg/New York, Springer, 2002). 
Jaspers, Karl, Der philosophische Glaube (München, Piper \& Co, 1948).

Kant, Immanuel, Grundlegung zur Metaphysik der Sitten (Riga, Johann Friedrich Hartknoch, 1786; edisi Suttgart, Philipp Reclam Jun., 1976).

Kant, Immanuel, Kritik der reinen Vernunft (Königsberg, 1787; edisi Stuttgart, Philipp Reclam Jun., 1975).

Kelsen, Hans, Was ist Gerechtigkeit? (Stuttgart, Philip Reclam, [1953] 2010).

Konfuzius, Gespräche. Lun Yü, terjemahan Richard Wilhelm (München, dtv $\mathrm{CH}$ Beck, [2005] 2007).

Kuhn Thomas, The Structure of Scientific Revolutions (Chicago, University of Chicago Press, 1962).

Kusumohamidjojo, Budiono, Filsafat Kebudayaan: Proses Realisasi Manusia (Yogyakarta, Jalasutra, 2009).

Kusumohamidjojo, Budiono, Filsafat Tiongkok: Sebuah Pengantar Komprehensif (Yogyakarta, Jalasutra, 2010)

Kusumohamidjojo, Budiono, "The terrain of the future: Life will be like bicycle riding", dalam The Jakarta Post (Jakarta, 16 September 2011).

Liu, JeeLoo, An Introduction To Chinese Philosophy: from Ancient Philosophy to Chinese Buddhism (Malden MA, Blackwell, [2006] 2008).

Nietzsche, F.W., Jenseits von Gut und Böse: Vorspiel einer Philosophie der Zukunft (München, Goldmann Verlag, (1886) 1996).

Palmer, John, Palmer, Parmenides, http://plato.stanford.edu/entries/ parmenides/, <jpalmer@phil.ufl.edu>, Copyright (C) 2008 (2015-03-30).

Palmer, John, Zeno of Elea, http://plato.stanford.edu/entries/zeno-elea/, <jpalmer@phil.ufl.edu>, Copyright (C) 2012 (2015-03-30).

Popper, Sir Karl Raimund, Conjectures and Refutations: The Growth of Scientific Knowledge (London, Routledge, 1963).

Rahardjo, Satjipto, Ilmu Hukum (Bandung, PT Citra Aditya Bhakti, 2000).

Rawls, John, A Theory of Justice (Harvard UP, [1971] 1991).

Rüthers, Bernd, Rechtstheorie (München, CH Beck, 2005).

Rüthers, Bernd, Das Ungerechte an der Gerechtigkeit (Tübingen, Mohr Siebeck, 2009).

Sandel, Michael, Justice: What's the Right Thing to do? (New York, Farrar, Straus \& Giroux, 2009).

Sen, Amartya, The Idea of Justice (London, Penguin Group, 2010).

Suriasumantri, Jujun, Filsafat Ilmu: Sebuah Pengantar Populer (Jakarta, Pustaka Sinar Harapan, 1994).

Valentiner, Theodor, Kant und seine Lehre, eine Einfuhrung in die kritische Philosophie (Stuttgart, Philipp Reclam Jun., [1960] 1976).

Williams, Bernard, Truth and Truthfulness, Princeton and Oxford, Princeton UP, 2002.

Wimmer, Franz Martin, Interkulturelle Philosophie, Wien, WUV Facultas, 2004.

Website:

Nusantara, Maula, Biografi Singkat Syekh Siti Jenar, Agustus 29, 2011, dalam: 
https://maulanusantara.wordpress.com/2011/08/29/biografi-singkat-syekh-sitijena/ (2015-02-20).

Raksa, Aji, 7 Versi Kematian Syekh Siti Jenar, dalam:

http://ajiraksa.blogspot.com/2012/05/7-versi-kematian-syekh-siti-jenar.html (2015-02-20) . 